\title{
PENGGUNAAN METODE BERMAIN PERAN DAN MEDIA GAMBAR (ROLE PLAYING) DALAM MENINGKATKAN HASIL BELAJAR IPS TEMA JENIS PEKERJAAN MELALUI DI SD NEGERI LIMO 1 DEPOK
}

\author{
MUNIROH \\ NIM. 825533056 \\ Email : munirohlimosatu@gmail.com
}

\begin{abstract}
ABSTRAK
Penelitian ini bertujuan untuk meningkatkan hasil belajar IPS dengan penggunaan metode bermain peran (role playing) dan menggunakan media gambar bagi siswa kelas III SD Negeri Limo 1 Depok tahun pelajaran 2015/2018. Berdasarkan hasil penelitian perbaikan pembelajaran, Hasil prasiklus, tingkat ketuntasan belajar peserta didik dengan KKM 70 hanya 4 dari 40 peserta didik atau 10\% dengan nilai rata-rata 59,50 dan hasil pengamatan peserta didik yang menjawab pertanyaan dengan benar sebesar 10\%. Pada siklus I, ada 23 peserta didik yang mencapai nilai KKM atau sebesar 57,50\% dengan nilai rata-rata 68,25 dan hasil pengamatan peserta didik menjawab benar sebesar 67,50\%. Nilai rata-rata yang diperoleh pada siklus I masih dibawah KKM sehingga dilanjutkan perbaikan pada siklus II. Pada siklus II dengan menambahkan metode bermain peran (role playing) dan media gambar, hasil belajar mencapai nilai rata-rata $85,25 \%$ dengan ketuntasan belajar peserta didik sebesar $100 \%$. Semua peserta didik pada siklus II memperoleh nilai di atas KKM serta hasil pengamatan peserta didik yang dapat menjawab sebesar 90\%. Metode bermain peran (role playing) dan media gambar meningkatkan hasil belajar peserta didik secara signifikan pada pembelajaran IPS materi jenis-jenis pekerjaan di kelas 3 SD Negeri Limo 1 Kecamatan Limo Kota Depok.
\end{abstract}

Kata Kunci: hasil belajar IPS, metode bermain peran (role playing).

\section{PENDAHULUAN}

\section{A. Latar Belakang Masalah}

Dalam mengembangkan kemampuan siswa, pendidik harus mampu mengelola proses pembelajaran dengan baik. Proses pembelajaran yang baik dan berkualitas memiliki fungsi dan tujuan untuk mengaktifkan siswa di dalam kelas serta meningkatkan pemahaman siswa terhadap pelajaran. Pembelajaran dikatakan berhasil dan berkualitas, apabila siswa terlibat 
secara aktif dalam proses pembelajaran di kelas, serta meningkatnya pemahaman siswa di dalam kelas. Untuk meningkatkan aktivitas dan pemahaman siswa di dalam kelas, maka perlu dibuat suatu rencana pembelajaran yang baik (Sulfemi, $2013: 17-26$ ).

Pembelajaran IPS khususnya di sekolah dasar, menunjukan indikasi bahwa pola pembelajaran yang dikembangkan oleh guru cenderung bersifat pada buku sumber. Hanya memindahkan pengetahuan secara utuh yang ada di ketahui guru kepada siswa. Pola pembelajaran yang demikian menyebabkan siswa jenuh, siswa tidak diajarkan berpikir secara logis hanya mementingkan pemahaman dan hafalan. Hal ini yang membuat pelajaran ini kurang digemari banyak siswa, pembelajar IPS terkesan tidak menarik bagi siswa karena ruang lingkupnya yang luas. Kejenuhan dalam pembelajaran IPS akan membuat siswa kurang fokus dalam belajar (Fajartriani dan Sulfemi, $2014:$ 17-26).

Proses pembelajaran yang menyenangkan merupakan salah satu faktor yang dapat menunjang keberhasilan suatu pembelajaran. Untuk mengatasi pembelajaran IPS agar tidak monoton dan lebih bervariasi, maka dapat digunakan media pembelajaran dan metode mengajar yang sesuai. (Arsyad \& Sulfemi, 2018 : : 41 - 46))

Metode pembelajaran yang diterapkan oleh guru kurang maksimal, sehingga masih kurang menggali kemampuan siswa untuk menemukan ideide baru dan berdiskusi. Berdasarkan pengamatan penulis, untuk meningkatkan kualitas pembelajaran IPS di sekolah, semua aspek harus berperan maksimal seperti kualitas guru harus maksimal dalam mengajar, sarana dan prasarana yang harus memadai, kondisi iklim yang kondusif untuk kenyamanan pembelajaran dan media-media yang bisa membantu pemahaman siswa terhadap materi yang diajarkan (Badar dan Sulfemi, 2018 : 1-10).

Berdasarkan pengamatan awal terhadap proses pembelajaran IPS di SD Negeri Limo 1, pelaksanaan proses pembelajaran guru masih belum memberdayakan seluruh potensi dirinya sehingga sebagian besar siswa 
belum mampu mencapai KKM pada materi jenis-jenis pekerjaan. Beberapa siswa belum belajar pada tingkat pemahaman, siswa baru mampu menghafal fakta dan konsep pada tingkat ingatan. Terkait belum optimalnya hasil belajar IPS siswa kelas III SD Negeri Limo 1 maka penulis berupaya untuk menerapkan penggunaan alat peraga gambar dan metode pembelajaran role playing (bermain peran) yang bertujuan pada kegiatan pembelajaran yang aktif, kreatif, efektif, dan menyenangkan.

Berdasarkan kondisi tersebut maka penulis melakukan penelitian tindakan kelas yang berfokus pada masalah seperti yang telah diuraikan di atas, yakni Meningkatkan Hasil Belajar IPS Tema Jenis Pekerjaan Melalui Metode Bermain Peran (Role Playing) dan Media Gambar Di Kelas III SD Negeri Limo 1 Depok

\section{KAJIAN PUSTAKA}

\section{A. Pengertian Pembelajaran IPS Sekolah Dasar}

Peristiwa belajar dan pembelajaran merupakan kegiatan yang tidak dapat dipisahkan dalam kehidupan manusia. Kegiatan belajar yang disertai dengan proses pembelajaran akan lebih terarah dan sistematik daripada belajar yang hanya semata-mata dan pengalaman dalam kehidupan sosial di masyarakat. Pembelajaran adalah suatu yang dilakukan oleh siswa, bukan dibuat untuk siswa. Ilmu sosial ini menurut Mackenzie, ilmu sosial adalah semua bidang ilmu yang berkenaan dengan manusia dalam konteks sosialnya atau manusia sebagai anggota masyarakat Sardjiyo (1975: 122). Menurut Jarolimek, studi sosial bersifat praktis yaitu memberikan kemampuan anak didik dalam mengelola dan memanfaatkan kekuatan fisik dan sosial dalam menciptakan kehidupan yang serasi (Sulfemi, $2017: 1-8)$.. IPS lahir dari keinginan para pakar pendidikan untuk membekali para siswa supaya nantinya mereka mampu menghadapi dan menangani permasalahan dimasyarakat. Melalui mata pelajaran IPS, siswa diarahkan untuk dapat menjadi warga negara Indonesia yang demokratis, dan bertanggung jawab, serta warga dunia yang cinta damai (Sulfemi dan Lestari, 2017 : 1-16). 
Ilmu pengetahuan sosial sebagai mata pelajaran tidak semata membekali ilmu saja lebih dari itu membekali juga sikap atau nilai dan keterampilan dalam hidup bermasyarakat sehingga mereka mengetahui benar lingkungan, masyarakat dan bangsanya dengan berbagai karakteristiknya. Menurut Sapriya (2014: 20) IPS di sekolah dasar merupakan nama mata pelajaran yang berdiri sendiri sebagai integrasi dari sejumlah konsep disiplin ilmu sosial, humaniora, sains bahkan berbagai isu dan masalah sosial kehidupan. Pembelajaran IPS SD mengkaji seperangkat peristiwa, fakta, konsep, dan generalisasi yang berkaitan dengan isu sosial, memuat materi geografi, sejarah, sosiologi, dan ekonomi. Dari beberapa pendapat para ahli dapat penulis sampaikan bahwa pembelajaran IPS di Sekolah Dasar adalah suatu usaha agar menciptakan kondisi yang memudahkan siswa untuk belajar dan memperrdayakan potensinya sehingga menguasai kompetensi secara optimal.

\section{B. Pengertian Hasil Belajar}

Belajar merupakan suatu proses, suatu kegiatan dan bukan suatu hasil atau tujuan Hamalik (2011: 27). Belajar bukan hanya mengingat, akan tetapi lebih luas daripada itu, yakni mengalami. Hasil belajar merupakan kulminasi dari suatu proses yang telah dilakukan dalam belajar Anitah (2014: 219). Hasil belajar merupakan refleksi keleluasaan, kedalaman, dan kompleksitas dan digambarkan secara jelas serta dapat diukur dengan teknik-teknik penilaian tertentu. Bukti bahwa seseorang telah belajar ialah terjadinya perubahan tingkah laku pada seseorang tersebut, misalnya dari tidak tahu menjadi tahu, dan dari tidak mengerti menjadi mengerti Hamalik (2010: 30). Hasil belajar tampak terjadinya perubahan tingkah laku pada diri siswa yang dapat diamati, diukur dalam perubahan pengetahuan, sikap, dan keterampilan. Oleh karena itu penilaian hasil belajar mempunyai peranan yang penting dalam proses belajar (Sulfemi, 2015 : 71-83).

Berdasarkan uraian di atas, hasil belajar diperoleh setelah siswa mengalami berbagai kegiatan belajar yang menyebabkan perubahan dalam 
dirinya. Hasil belajar adalah perubahan perilaku atau kemampuan siswa setelah menerima pengalaman belajar yang dapat diukur. Berdasarkan pengertian belajar tersebut, dapat penulis sampaikan bahwa belajar merupakan proses interaksi yang dilakukan oleh individu dengan lingkungan sehingga menimbulkan perubahan perilaku ke arah yang lebih baik.

\section{Pengertian tentang Metode Bermain Peran (Role Playing)}

Role Playing atau bermain peran adalah pembelajaran bahasa yang berprinsip komunikasi yang dapat menimbulkan hubungan situasi sosial dalam kegiatan pembelajaran sehingga dapat meningkatkan keaktifan siswa dalam penggunaan bahasa secara lisan yang mengandung arti atau makna Amiruddin (2018: 95). Sedangkan menurut Hamalik (2014: 214), Role playing adalah metode pembelajaran dimana siswa bertindak dan mengekspresikan perasaan dan pendapatnya, siswa menerima karakter, perasaan, dan ide-ide orang lain dalam situasi yang khusus. Dalam role playing murid dikondisikan pada situasi tertentu di luar kelas meskipun saat itu pembelajaran terjadi di dalam kelas. Selain itu, role playing sering kali dimaksudkan sebagai suatu bentuk aktivitas dimana pembelajar membayangkan dirinya seolah-olah berada di luar kelas dan memainkan peran orang lain.

Pembelajaran ini pada umumnya dilakukakan lebih dari satu orang, hal itu tergantung kepada apa yang diperankan. Pada metode bermain peran titik tekanannya terletak pada keterlibatan emosional dan pengamatan indera ke dalam suatu situasi maslah yang secara nyata dihadapi. Murid diperlakukan sebagai subyek pembelajaran secara aktif melakukan kegiatan bertanya dan menjawab, bersama teman-temannya pada situasi tertentu. Jadi, dalam pembelajaran murid harus aktif karena tanpa adanya aktivitas maka proses pembelajaran tidak mungkin terjadi. Pengorganisasian kelas secara berkelompok, masing-masing kelompok memperagakan skenario yang telah dipersiapkan guru. Peserta didik diberi kebebasan berimprovisasi namun masih dalam batas-batas skenario dari guru. 
Langkah Metode Pembelajaran Role Playing adalah sebagai berikut:

a. Guru menyusun/mempersiapkan skenario yang akan ditampilkan.

b. Menunjuk beberapa siswa untuk mempelajari skenario dalam waktu beberapa hari sebelum pelaksanaan kegiatan belajar mengajar.

c. Guru membentuk kelompok siswa untuk memerankan skenario ke depan kelas.

d. Memberikan penjelasan tentang kompetensi yang ingin dicapai.

e. Memanggil para siswa yang sudah ditunjuk untuk melakonkan skenario yang sudah dipersiapkan.

f. Masing-masing siswa berada di kelompoknya sambil mengamati skenario yang sedang diperagakan.

g. Setelah selesai ditampilkan masing-masing siswa diberikan lembar kerja untuk memberi penilaian atas penampilan masing-masing kelompok.

h. Masing-masing kelompok menyampaikan hasil kesimpulannya.

i. Guru memberikan kesimpulan secara umum.

j. Evaluasi.

k. Penutup.

Keunggulan Metode Pembelajaran Bermain Peran (Role Playing)

Ada beberapa keunggulan dengan menggunakan Metode Pembelajaran Bermain Peran (Role Playing), diantaranya adalah:

1) Dapat berkesan dengan kuat dan tahan lama dalam ingatan siswa

2) Meningkatkan motivasi dan semangat dalam diri siswa serta menumbuhkan rasa kebersamaan

3) Menjadikan kelas lebih dinamis dan penuh antusias

4) Siswa belajar secara aktif dengan memerankan sesuatu yang akan dibahas dalam proses belajar.

Kelemahan Metode Pembelajaran Bermain Peran (Role Playing)

Disamping memiliki keunggulan, metode pembelajaran bermain peran (role playing) mempunyai kelemahan, diantaranya adalah:

1) Bermain peran memakan waktu yang banyak.

2) Siswa sering mengalami kesulitan untuk memerankan peran secara baik. 
3) Jika siswa dan kelas tidak dipersiapkan dengan baik ada kemungkinan siswa tidak akan melakukan dengan sungguh-sungguh.

4) Tidak semua materi pelajaran ddapat disajikan melalui metode ini.

Menururt Sulfemi dan Nurhasanah. (2018 : 151-158) bermain peran (role playing) pada prinsipnya merupakan metode untuk menghadirkan peranperan yang ada dalam dunia nyata ke dalam suatu pertunjukkan peran di dalam kelas/pertemuan. Dapat penulis simpulkan bahwa, metode bermain peran (role playing) merupakan suatu pembelajaran bahasa yang berprinsip pada komunikasi yang dapat menimbulkan hubungan situasi sosial dalam kegiatan pembelajaran sehingga dapat meningkatkan keaktifan siswa dalam penggunaan bahasa secara lisanyang mengandung arti atau makna.

\section{Pengertian tentang Media Gambar}

Media adalah alat bantu apa saja yang dapat dijadikan sebagai penyalur pesan guna mencapai tujuan pengajaran Syaiful dan Aswan (2013: 121). Media sebagai alat bantu dalam proses belajar mengajar karena media sangat berperan dalam dalam menyampaikan pesan-pesan dari bahan pelajaran yang diberikan oleh guru kepada anak didik. Fleming dalam Arsyad Azhar (2014: 306) Media adalah penyebab atau alat yang turut campu tangan dalam dua pihak dan mendamaikannya. Sedangkan menurut Syaiful dan Aswan (2013: 124) media gambar adalah media yang hanya mengandalkan indra penglihatan. Media gambar ini dapat membantu siswa untuk mengungkapkan informasi yang terkandung dalam masalah sehingga hubungan antar komponen dalam masalah tersebut dapat terlihat dengan lebih jelas. (Sulfemi, $2015: 1-10$ ).

Dalam Azhar Arsyad (2014: 306), kelebihan menggunakan media gambar dalam kegiatan belajar mengajar adalah:

1. Sifatnya konkrit

2. Gambar dapat mengatasi batasan ruang dan waktu.

3. Media gambar dapat mengatasi keterbatasan pengamatan.

4. Dapat memperjelas suatu masalah, dalam bidang apa saja. 
5. Murah harganya, mudah didapatkan dan digunakan.

Sedangkan kelemahan media gambar adalah:

1. Gambar menekankan persepsi indera mata.

2. Gambar terlalu kompleks kurang efektif untuk kegiatan pembelajaran.

3. Ukurannya sangat terbatas untuk kelompok besar.

Dengan demikian, pada saat guru mengajar menggunakan strategi ini, penekanan perlu dilakukan bahwa gambar yang dibuat tidak perlu sempurna, terlalu bagus atau terlalu detail. Pada intinya perlu diperhatikan media gambarnya mampu memperjelas permasalahan yang dihadapi.

\section{PELAKSANAAN PENELITIAN PERBAIKAN PEMBELAJARAN}

\section{A. Subyek, Tempat dan Waktu Penelitian, Pihak yang membantu}

\section{Subyek dan Tempat Penelitian}

Subyek Penelitian adalah peserta didik Kelas III yang berjumlah 40 siswa, terdiri dari 20 laki-laki dan 20 perempuan. Penelitian ini dilakukan di SDN Limo I, Jl.Raya Limo Gg. H. Midi 2 Kecamatan Limo Kota Depok.

\section{Waktu Penelitian}

Penelitian Tindakan Kelas dilaksanakan mulai 11 Januari 2018. Penelitian dimulai prasiklus, dilanjutkan dengan siklus 1 pada tanggal 18 Januari 2018 dan siklus 2 yang dilakukan pada tanggal 25 Januari 2018.

\section{B. Desain Prosedur Perbaikan Pembelajaran}

Desain prosedur pembelajaran yang dipergunakan dalam penelitian ini, penulis melaksanakan 4 tahap pada setiap siklusnya, yaitu :

1. Tahap perencanaan

2. Tahap pelaksanaan

3. Tahap observasi

4. Tahap refleksi

Adapun pelaksanaan penelitian tersebut didskripsikan sebagai berikut :

\section{Prasiklus}

\section{a. Perencanaan}


Dalam kegiatan perencanaan, guru merancang rencana tindakan yang akan dilakukan, seperti :

1) Membuat Rencana Perbaikan Pembelajaran ( RPP ) yang sesuai

2) Memilih metode ceramah sebagai pengantar materi

3) Membuat skenario pembelajaran yang berisikan langkah-langkah dalam proses pembelajaran.

4) Mempersiapkan lembar observasi

5) Membuat alat evaluasi

\section{b. Pelaksanaan/Tindakan}

Dalam kegiatan pembelajaran pada prasiklus, peneliti mencoba untuk mendesain proses pembelajaran agar peserta didik menguasai dengan menggunakan metode ceramah yang disusun dalam kegiatan pembelajaran sebagai berikut :

\section{1) Kegiatan Awal}

Apersepsi

a) Mengkondisikan kelas/siswa

b) Mengabsen keadaan siswa

c) Tepuk semangat sebelum memulai pelajaran

d) Mengulang materi tentang jenis-jenis pekerjaan sebagai apersepsi

e) Mengajukan beberapa pertanyaan tentang jenis-jenis pekerjaan

- Sebutkan jenis-jenis pekerjaan

- Apakah manfaat seseorang harus mencari pekerjaan

f) Menjelaskan tujuan dan kegiatan pembelajaran yang akan dilakukan

\section{2) Kegiatan Inti}

\section{Eksplorasi}

a) Siswa menyimak penjelasan guru tentang jenis-jenis pekerjaan sebagai penghasilan untuk kebutuhan sehari-hari.

b) Siswa mengamati gambar seorang yang sedang bekerja yang ditempelkan pada pada papan tulis. 


\section{Elaborasi}

a) Guru membagi siswa membentuk menjadi 4 kelompok.

b) Siswa diberikan naskah teks bermain peran tentang jenis-jenis pekerjaan.

c) Siswa diberikan kesempatan oleh guru untuk membaca dan memahami naskah teks bermain peran.

d) Siswa melakukan kegiatan bermain peran sesuai perintah guru.

e) Setelah perwakilan kelompok melakukan kegiatan bermain peran, siswa melakukan tanya jawab menyebutkan jenis-jenis pekerjaan.

f) Siswa ditugaskan kedepan untuk menuliskan 2 jenis pekerjaan.

\section{Konfirmasi}

a) Siswa dan guru menyimpulkan hasil materi tentang jenis-jenis pekerjaan.

b) Siswa bertanya jawab dengan guru dalam rangka memberi penguatan kembali terhadap materi mengenal jenis-jenis pekerjaan.

\section{3) Kegiatan akhir}

a) Guru menyimpulakan pembelajaran.

b) Mengevaluasi pembelajaran (post-tes).

c) Tindak lanjut dengan pemberian tugas rumah.

d) Tanya jawab secara lisan tentang materi yang diajarkan.

e) Berdoa dan salam.

\section{c. Observasi / pengamatan}

Berdasarkan pengamatan dan observasi saat guru mengajar, yang menjadi permasalahannya dalam pembelajaran tersebut adalah :

1) Peserta didik kurang termotivasi dalam pembelajaran.

2) Peserta didik masih pasif dalam pembelajaran.

3) Rendahnya tanggung jawab peserta didik dalam mengerjakan tugas.

4) Pembelajaran membosankan bagi peserta didik. 
5) Guru belum menggunakan metode mengajar yang tepat.

6) Guru kurang memotivasi terhadap keberhasilan peserta didik.

7) Guru belum menggunakan alat peraga yang konkrit sesuai dengan materi.

\section{d. Refleksi}

Kegiatan refleksi ini bertolak dari hasil observasi yang dilakukan guru dan supervisor selama proses pembelajaran. Dari hasil pelaksanaan prasiklus, hasil evaluasi menunjukkan perolehan yang kurang maksimal. Setelah dievaluasi pemilihan metode kurang tepat. Untuk mengatasi masalah tersebut, peneliti harus melakukan perbaikan pengajaran dengan menambah metode pembelajaran yang sesuai dengan kompetensi dasar pada siklus 1 .

\section{Siklus 1}

Siklus 1 dalam Penelitian Tindakan Kelas terdiri dari perencaan, pelaksanaan, pengamatan dan refleksi sebagai berikut :

\section{a. Perencanaan}

1) Penelitian merefleksi dan mengidentifikasi pembelajara prasiklus untuk menentukan perbaikan pembelajaran.

2) Menyusun RPP dengan menggunakan metode pembelajaran ceramah dan penugasan.

3) Membuat lembar kerja siswa.

4) Membuat lembar observasi untuk mengamati keaktifan belajar siswa.

5) Membuat alat evaluasi.

\section{b. Pelaksanaan/Tindakan}

Dalam kegiatan perbaikan pembelajaran pada siklus 2 peneliti mencoba untuk mendesain proses pembelajaran agar peserta didik menjadi aktif dan kreatif dengan menggunakan metode bermain peran yang disusun dalam kegiatan pembelajaran sebagai berikut :

\section{1) Kegiatan Awal}

Apersepsi 
a) Mengkondisikan kelas/siswa.

b) Mengabsen keadaan siswa.

c) Tepuk semangat sebelum memulai pelajaran.

d) Mengulang materi tentang jenis-jenis pekerjaan sebagai apersepsi.

e) Mengajukan beberapa pertanyaan tentang jenis-jenis pekerjaan.

- Sebutkan jenis-jenis pekerjaan.

- Apakah manfaat seseorang harus mencari pekerjaan.

f) Menjelaskan tujuan dan kegiatan pembelajaran yang akan dilakukan.

\section{2) Kegiatan inti}

\section{Eksplorasi}

Dalam kegiatan ekplorasi, peserta didik :

a) Mendengarkan penjelasan guru.

b) Mengamati gambar yang ditempel pada papan tulis.

Dalam kegiatan ekplorasi, guru :

a) Mempasilitasi terjadinya interaksi antara peserta didik dalam kelompoknya agar tetap aktif.

b) Memberikan peluang pada anggota kelompok untuk mencari gambar yang sesuai diperintahkan oleh guru.

\section{Elaborasi}

Dalam kegiatan elaborasi, peserta didik :

a) Menjawab pertanyaan guru dengan baik

b) Melaporkan hasil tugas secara lisan dan tertulis, secara kelompok

c) Menanggapi laporan atau pendapat teman

Dalam kegiatan elaborasi, guru :

a) Membiasakan peserta didik untuk menyimak

b) Membiasakan peserta didik untuk berpikir kritis menganalisis dan mampu memecahkan masalah yang dihadapi.

\section{Konfirmasi}


Dalam kegiatan konfirmasi, peserta didik melakukan refleksi terhadap pengalaman belajarnya

Dalam kegiatan konfirmasi, guru sebagai fasilitator dan nara sumber

\section{3) Kegiatan akhir}

1) Guru mengajukan pertanyaan sekitar materi yang diajarkan

2) Guru dan peserta didik menyimpulkan materi yang diajarkan

3) Peserta didik menyelesaikan post-tes

\section{c. Observasi/Pengamatan}

Berdasarkan pengamatan dan observasi saat guru mengajar, yang menjadi permasalahan dalam pembelajaran tersebut adalah :

1) Peserta didik kurang termotivasi dalam pembelajaran

2) Rendahnya tanggung jawab peserta didik dalam mengerjakan tugas

3) Guru belum menggunakan metode pembelajaran yang tepat

4) Guru belum menggunakan alat peraga yang konkrit sesuai dengan materi

\section{d. Refleksi}

Berdasarkan refleksi yang telah dilakukan, ditemukan beberapa kekuatan dan kelemahan yang dapat dijadikan acuan untuk mengukur keberhasilan dalam proses pembelajaran. Adapun kekuatan dan kelemahan dalam perbaikan pembelajaran pada siklus 1 sebagai berikut:

\section{1) Kekuatan}

a) Keaktifan peserta didik mulai terlihat walaupun belum maksimal.

b) Peserta didik satu dengan yang lainnya saling berinteraksi.

c) Peserta didik mulai berani tampil di depan kelas untuk mempresentasikan hasil perhitungan kelompoknya.

d) Guru memberikan metode yang lebih baik dalam materi pelajaran.

\section{2) Kelemahan}


a) Kemampuan guru memotivasi belajar siswa belum maksimal.

b) Masih ada beberapa peserta didik yang mengobrol.

c) Guru kurang membimbing peserta didik dalam pembiasaan berani mengeluarkan pendapat.

d) Hasil belajar peserta didik masih belum maksimal.

Fokus perbaikan tersebut akan dilaksanakan di dalam Rencana Perbaikan Pembelajaran (RPP) pada siklus 2.

\section{Siklus 2}

\section{a. Perencanaan}

Penelitian membuat rencana perbaikan pembelajaran berdasarkan refleksi siklus 1 untuk mencapai tujuan pembelajaran yang lebih baik, dengan persiapan :

1) Guru menentukan tujuan perbaikan pembelajaran.

2) Menyusun RPP dengan menambah metode bermain peran.

3) Menyiapkan alat peraga media gambar yang ada pada papan tulis.

4) Membuat lembar pengamatan partisipasi peserta didik.

5) Menyusun alat evaluasi.

6) Berkonsultasi dengan supervisor untuk perbaikan siklus 2.

\section{b. Pelaksanaan/Tindakan}

\section{1) Kegiatan awal}

Apersepsi/motivasi

a) Mengkondisikan kelas,mengabsen keadaan siswa.

b) Memberikan motivasi dengan tepuk semangat.

c) Mengulang materi tentang jenis-jenis pekerjaan.

d) Membentuk peserta didik menjadi 4 kelompok.

\section{2) Kegiatan inti}

\section{Eksplorasi}

Dalam kegiatan eksplorasi, peserta didik :

a) Mendengarkan penjelasan guru.

b) Memilih pakaian propesi sesuai yang ditunjuk guru.

Dalam kegiatan eksplorasi, guru : 
a) Guru menjelaskan tentang jenis-jenis pekerjaan.

b) Guru memfasilitasi interaksi antar siswa dalam kelompoknya.

\section{Elaborasi}

Dalam kegiatan elaborasi, peserta didik :

a) Menjawab pertanyaan guru dengan baik.

b) Mengerjakan tugas yang diberikan guru.

Dalam kegiatan elaborasi, guru :

a) Membiasakan peserta didik menyimak penjelasan guru.

b) Memfasilitasi peserta didik untuk dapat memberi tanggapan kepada pertanyaan dengan baik.

\section{Konfirmasi}

Dalam kegiatan konfirmasi, peserta didik :

a) Melakukan refleksi terhadap pengalaman belajarnya.

Dalam kegiatan konfirmasi, guru :

a) Memberi umpan balik positif kepada peserta didik.

b) Berperan sebagai fasilitator dan narasumber.

c) Memberi motivasi kepada peserta didik.

\section{3) Kegiatan Akhir}

a) Guru mengajukan pertanyaan sesuai materi yang diajarkan.

b) Guru dan peserta didik menyimpulkan materi yang diajarkan.

c) Peserta didik menyelesaikan post tes.

\section{c. Observasi / pengamatan}

Selama mengikuti proses perbaikan pembelajaran, peneliti melakukan pengamatan terhadap aktivitas peserta didik. Ada perubahan yang cukup baik dalam proses maupun hasil belajar peserta didik.Selesai diberikan evaluasi, mulai siklus 1 dengan nilai rata-rata 85,25 .

\section{d. Refleksi}

Setelah dilaksanakan pembelajaran yang telah diamati oleh pengamat, kemudian peneliti mengadakan refleksi hasil tindakan 
putaran kedua atau siklus 2, temuan hasil refleksi ini menunjukan bahwa :

a) Adanya peningkatan keaktifan siswa dalam proses pembelajaran

b) Adanya peningkatan hasil belajar siswa pada pelajarn IPS sehingga dapat mencapai nilai KKM yang ditetapkan yaitu 70,00.

Berdasarkan hasil refleksi pada siklus ke 2 peneliti bersama pengamat menyimpulkan agar tidak perlu diadakan lagi siklus 3, karena pada siklus 2 sudah menunjukan adanya peningkatan ataupun perubahan yang positif dari tiap-tiap siklus yang mearah pada tujuan pembelajaran atau fokus penelitian.

\section{Tehnik Analisis Data}

1. Data

Sumber data dalam penelitian adalah siswa yang duduk dikelas III SD Negeri Limo I, sedangkan jenis data yang diharapkan yaitu meliputi hasil observasi terhadap proses belajar dan data siswa.

2. Teknik Pengumpulan Data

a. Obsevasi

Observasi dilakukan untuk mengamati aktivitas belajar siswa.

b. Jurnal Harian

Jurnal harian merupakan catatan harian pada penelitian untuk merekam semua kegiatan dalam proses pembelajaran.

c. Data tes kemampuan pada siklus I dan II

Data tes merupakan data kuantitatif yang diambil dari setiap siklus melalui pre tes dan post tes.

3. Analisa Data

a. Data observasi

Data ini diambil pengamatan yang dilakukan oleh peneliti sebagai orang yang terlibat aktif dalam pelaksanaan tindakan dibantu oleh rekan yang telah bersedia menjadi supervisor 2 .

b. Data Tes Kemampuan 
Data Tes Kemampuan pada setiap siklus diakumulasikan pada setiap tabel, kemudian dihitung rata - rata hasil tes pada setiap pertemuan. Demikianlah data-data yang terkumpul kemudian dibandingkan antara prasiklus, siklus 1, dan siklus 2, kemudian disajikan dalam bentuk tabel dan grafik yang akan ditampilkan pada bab IV.

\section{HASIL PENELITIAN DAN PEMBAHASAN}

\section{A. Deskripsi Hasil Penelitian Perbaikan Pembelajaran}

Penelitian Tindakan Kelas (PTK) yang telah dilaksanakan peneliti dalam waktu 3 kali pertemuan yaitu prasiklus, siklus 1 dan siklus 2. Lama pembelajaran tiap siklus adalah $2 \times 35$ menit ( 2 jam pelajaran). Selama kegiatan perbaikan pembelajaran, peneliti dibantu oleh teman sejawat untuk mengobservasi dan memberikan masukan. Dalam kegiatan pembelajaran yang dilaksanakan belum mencapai tujuan yang diinginkan, yang menjadi permasalah dalam prasiklus ini adalah:

1. Peserta didik kurang termotivasi dalam mengikuti kegiatan pembelajaran.

2. Nilai rata-rata hasil evaluasi 59,50 masih di bawah KKM yang telah ditetapkan yaitu 70 .

3. Peserta didik masih pasif dalam mengikuti pembelajaran.

4. Rendahnya tanggung jawab peserta didik dalam mengerjakan tugas.

5. Guru belum menggunakan metode pembelajaran yang tepat.

6. Media yang dipakai belum sesuai dengan materi yang diajarkan.

Pada prasiklus ini, hasil rata-rata diperoleh hanya sebesar 59,50 dan yang tidak mencapai KKM yaitu sebanyak 36 dari 40 peserta didik atau sebesar $90 \%$. Berdasarkan pengamatan peserta didik yang dapat menjawab pertanyaan guru hanya ada 4 peserta didik atau sebesar $10 \%$. Berikut hasil rekapitulasi nilai dan pengamatan peserta didik pada prasiklus mata pelajaran IPS. 
Pada pembelajaran siklus 1, peneliti menambahkan metode bermain peran (role playing). Pada pembelajaran ini, nilai rata-rata mengalami peningkatan menjadi 68,25 sedangkan peserta didik yang belum mencapai KKM sebanyak 17 dari 40 peserta didik atau sebesar 42,50\%. Peserta didik dapat menjawab pertanyaan guru pun mengalami peningkatan yaitu 37,50\%. Namun kenaikan tersebut masih belum mencapai KKM yang diharapkan.

Dari hasil pengamatan dan observasi saat proses pembelajaran di kelas, yang menjadi permasalahan adalah:

1. Peserta didik kurang termotivasi dalam mengikuti pembelajaran.

2. Nilai rata-rata hasil evaluasi 68,25 masih di bawah KKM yang ditetapkan yaitu sebesar 70 .

3. Masih kurangnya tanggung jawab peserta didik dalam mengerjakan tugas.

4. Guru belum menggunakan metode pembelajaran yang tepat.

5. Guru belum menggunakan media pembelajaran yang dapat memudahkan siswa dalam menerima materi.

Berdasarkan hasil evaluasi pada siklus 1, pembelajaran IPS materi jenis-jenis pekerjaan belum mencapai hasil yang diharapkan. Sehingga peneliti melanjutkan perbaikan pembelajaran pada siklus 2. Setelah peneliti memperbaiki pembelajaran dengan menambahkan metode bermain peran (role playing) dan media gambar, hasil belajar peserta didik menunjukkan peningkatan yang signifikan.

Rata-rata nilai yang diperoleh sebesar 85,25 . Semua peserta didik tuntas hasil nilainya di atas KKM, ketuntasan siswa 100\%. Dari hasil pengamatan, peserta didik yang dapat menjawab pertanyaan sebanyak 36 peserta didik atau sebesar $90 \%$. Berikut ini data hasil rekapitulasi nilai dan pengamatan peserta didik pada mata pelajaran IPS dalam bentuk tabel.

Berdasarkan tabel di atas, perbandingan perolehan nilai dan ketuntasan belajar pada prasiklus, siklus I, dan siklus II terus mengalami peningkatan. Perolehan nilai rata-rata berturut-turut sebesar 59,50;68,25 ; 
dan 85,25 . Tingkat ketuntasan pun menunjukkan peningkatan pada prasiklus sebesar $10 \%$, siklus I sebesar 57,50\% dan siklus II sebesar $100 \%$.

Dengan melihat tabel 9 di atas, pada pembelajaran prasiklus persentase peserta didik yang dapat menjawab pertanyaan guru dengan benar sebesar $10 \%$. Pada siklus I dan II persentase mengalami kenaikan, pada siklus I sebesar $65,50 \%$ dan siklus II sebesar $90 \%$.

\section{B. Pembahasan Hasil Perbaikan Pembelajaran}

Berdasarkan hasil observasi dan diskusi dengan teman sejawat, dapat dilihat bahwa hasil perbaikan pembelajaran menunjukkan adanya peningkatan. Hal tersebut dibuktikan dengan meningkatnya pemahaman peserta didik terhadap materi pembelajaran IPS pada tiap siklusnya. Pada prasiklus, pembelajaran hanya menggunakan metode ceramah saja, sehingga hasil yang diperoleh pada nilai rata-ratanya hanya 59,50 dengan hasil pengamatan peserta didik yang dapat menjawab pertanyaan dengan benar sebesar $10 \%$ dan ketuntasan belajar hanya $10 \%$. Pada siklus 1 , proses pembelajaran di kelas menggunakan metode ceramah, diskusi, dan bermain peran (role playing). Adanya peningkatan hasil belajar yang ditunjukkan dengan nilai rata-rata 68,25 dengan hasil pengamatan peserta didik yang dapat menjawab pertanyaan dengan benar sebesar 62,50\% dan ketuntasan belajar sebesar $57,50 \%$. Akan tetapi, hasil yang diperoleh peserta didik masih belum mencapai KKM yang diharapkan. Oleh karena itu, peneliti melanjutkan perbaikan pada pembelajaran siklus 2 .

Pada pembelajaran siklus 2, peneliti menambahkan metode bermain peran (role playing) dan media gambar. Dari pelaksanaan evaluasi pada siklus 2 terjadi peningkatan hasil belajar yang signifikan yaitu diperoleh nilai rata-rata 85,25 dengan pengamatan peserta didik yang dapat menjawab pertanyaan dengan benar sebesar 90\% dan ketuntasan belajar sebesar $100 \%$. Penggunaan metode bermain peran (role playing) dan media gambar berpengaruh pada hasil belajar peserta didik. Hal ini dapat membantu 
kesulitan peserta didik dalam proses belajar sehingga dapat meningkatkan pemahaman peserta didik terhadap pembelajaran IPS.

Berdasarkan hasil pembelajaran pada siklus 2, terdapat peningkatan hasil belajar pada mata pelajaran IPS materi jenis-jenis pekerjaan dengan menggunakan metode bermain peran (role playing) dan media gambar pada kelas 3 SDN Limo 1. Nilai rata-rata hasil belajar mencapai 85,25 dengan ketuntasan belajar mencapai $100 \%$ dan hasil pengamatan pada peserta didik yang dapat menjawab pertanyaan dengan benar sebesar $90 \%$. Oleh karena itu, peneliti tidak perlu melakukan perbaikan pembelajaran pada siklus berikutnya.

\section{KESIMPULAN DAN SARAN}

\section{A. Kesimpulan}

Berdasarkan hasil penelitian perbaikan pembelajaran, maka dapat disimpulkan sebagai berikut:

1. Hasil prasiklus, tingkat ketuntasan belajar peserta didik dengan KKM 70 hanya 4 dari 40 peserta didik atau 10\% dengan nilai rata-rata 59,50 dan hasil pengamatan peserta didik yang menjawab pertanyaan dengan benar sebesar $10 \%$. Pada siklus I, ada 23 peserta didik yang mencapai nilai KKM atau sebesar $57,50 \%$ dengan nilai rata-rata 68,25 dan hasil pengamatan peserta didik menjawab benar sebesar 67,50\%. Nilai ratarata yang diperoleh pada siklus I masih dibawah KKM sehingga dilanjutkan perbaikan pada siklus II. Pada siklus II dengan menambahkan metode bermain peran (role playing) dan media gambar, hasil belajar mencapai nilai rata-rata $85,25 \%$ dengan ketuntasan belajar peserta didik sebesar $100 \%$. Semua peserta didik pada siklus II memperoleh nilai di atas KKM serta hasil pengamatan peserta didik yang dapat menjawab sebesar $90 \%$.

2. Metode bermain peran (role playing) dan media gambar meningkatkan hasil belajar peserta didik secara signifikan pada pembelajaran IPS materi jenis pekerjaan di kelas 3 SD N Limo 1 Kecamatan Limo Kota Depok. 


\section{B. Saran}

Berdasarkan hal-hal yang dikemukakan dalam kajian penelitian ini selanjutnya dapat diajukan beberapa saran sebagai berikut:

1. Refleksi diri dalam perbaikan kemampuan pengajaran hendaknya sering dilakukan oleh seorang guru.

2. Penggunaan metode yang bervariasi pada proses pembelajararn akan membangkitkan semangat dan motivasi siswa pada pembelajaran tersebut.

3. Pengembangan diri hendaknya terus dilakukan untuk mencari inovasi baru dalam pembelajaran.

\section{DAFTAR PUSTAKA}

Amiruddin. (2018). Perencanaan Pembelajaran. Yogyakarta: Parama Ilmu.

Arsyad, Azhar \& Asfah, Rahman. (2014). Media Pembelajaran. Jakarta: PT RajaGrafindo Persada.

Arsyad, Arsyad, \& Sulfemi, Wahyu Bagja. (2014). Minat Siswa Tentang Keadministrasian dengan Hasil Belajar Administrasi Perkantoran. Edutecno 9 (2), 40-50.

Arsyad, Arsyad dan Sulfemi, Wahyu Bagja. (2018) Metode Role Playing Berbantu Media Audio Visual Pendidikan dalam Meningkatkan Belajar IPS. Jurnal Pendidikan Ilmu Pengetahuan Sosial Indonesia. 3 (2). $41-46$.

Badar, Dadan Samsul dan Sulfemi, Wahyu Bagja. (2014). Pengaruh Rasa Percaya Diri dan Motivasi Berprestasi Terhadap Kinerja di Kecamatan Ciampea Kabupaten Bogor. Edutecno. 10 (1), 1-10,

Djamarah, Syaiful Bahr, dan Aswan Zain. 2013. Strategi Belajar Mengajar. Jakarta: PT Rineka Cipta.

Fathurrohman, Muhammad. (2015). Model-model Pembelajaran Inovatif Alternatif Desain Pembelajaran yang Menyenangkan. Yogyakarta: Ar-Russ Media.

Fajartriani, Tia dan Sulfemi, Wahyu Bagja. (2014). Pengaruh Motivasi Kerja Guru dan Iklim Organisasi Terhadap Kinerja Guru SMA Negeri di Kecamatan Cigudeg. Edutecno. 8 (1), 17-26 
Hamalik, Oemar. (2010). Kurikulum dan Pembelajaran. Jakarta: Bumi Aksara.

Hamalik, Oemar. (2011). Kurikulum dan Pembelajaran. Jakarta: Bumi Aksara.

Hamalik, Oemar. (2014). Kurikulum dan Pembelajaran. Jakarta: Bumi Aksara.

Sapriya. (2014). Pendidikan IPS. Bandung: PT Remaja Rosdakarya Offset.

Sardjiyo, dkk. (2014). Pendidikan IPS di SD. Tangerang Selatan: Universitas Tebuka.

Sulfemi, Wahyu Bagja. (2013). Pengaruh Persepsi Siswa atas Kemampuan Pedagogik Guru dan Motivasi Belajar Siswa Terhadap Prestasi Belajar Ilmu Pengetahuan Sosial Siswa (Survei di SMK Swasta Kabupaten Bogor). Edutecno. 7 (2), 17-26.

Sulfemi, Wahyu Bagja. (2014). Pengaruh Motivasi dan Lingkungan Sekolah Terhadap Prestasi Belajar Sejarah Di SMA Negeri Leuwilang Kabupaten Bogor. Fascho : Kajian Pendidikan dan Sosial Kemasyarakatan 9 (2), 42-52

Sulfemi, Wahyu Bagja. (2015). Pengaruh Metode Pembelajaran Kontekstual dan Penggunaan Media Video Pendidikan Terhadap Hasil Belajar IPS. Edutecno 13 (2), 1-10

Sulfemi, Wahyu Bagja. (2016). Hubungan Persepsi Peserta Didik Tentang Kompetensi Guru Mata Pelajaran Sejarah dengan Hasil Belajar Mata Pelajaran Sejarah di Kelas X SMA Negeri 1 Pamijahan Kabupaten Bogor. Fascho, 5 (2), 52-70

Sulfemi, Wahyu Bagja. (2016). Hubungan antara Persepsi Guru pada Kepemimpian Kepala Sekolah dan Motivasi Guru dengan Kinerja guru dalam Proses Pembelajaran di SMA Negeri 1 Ciomas. Fascho : Kajian Pendidikan dan Sosial Kemasyarakatan, 5 (1), 36-55

Sulfemi, Wahyu Bagja. (2016). Perundang-Undangan Pendidikan. Bogor : Program Studi Administrasi Pendidikan STKIP Muhammadiyah Bogor.

Sulfemi, Wahyu Bagja dan Lestari, Ayu Hopilatul. (2017). Korelasi Kompetensi Pedagogik Guru dengan Prestasi Belajar Mata Pelajaran IPS Di SMP Muhammadiyah Pamijahan Kabupaten Bogor. Edutecno. 16 (1), $1-16$

Sulfemi, Wahyu Bagja dan Abdul Qodir. (2017). Hubungan Kurikulum 2013 Dengan Motivasi Belajar Peserta Didik Di SMK Pelita Ciampea. Edutecno 17 (2), 1-8.

Sulfemi, Wahyu Bagja. (2017). Analisis Pengaruh Motivasi Dan Disiplin Terhadap Kinerja Guru (Studi Kasus di SMA Negeri 1 Pamijahan Kabupaten Kabupaten Bogor). Prosiding Seminar Nasonal STKIP Muhammadiyah Bogor. 1 (1), 342-357 
Sulfemi, Wahyu Bagja dan Supriyadi, Dede. (2018). Pengaruh Kemampuan Pedagogik Guru dengan Hasil Belajar IPS. Edutecno 17 (1), 1-10.

Sulfemi, Wahyu Bagja dan Hilga Minati. (2018). Meningkatkan Hasil Belajar Peserta Didik Kelas 3 SD Menggunakan Model Picture And Picture dan Media Gambar Seri. JPSD. 4 (2), 228- 242.

Sulfemi, Wahyu Bagja dan Setianingsih. (2018), Penggunaan Tames Games Tournament (TGT) Dengan Media Kartu Dalam Meningkatkan Hasil Belajar. Journal of Komodo Science Education (JKSE. 1 (1), $1-14$

Sri Anitah W., dkk. (2014). Strategi Pembelajaran Di SD. Tangerang Selatan: Universitas Terbuka.

Yusfiriadi, Yusfitriadi dan Sulfemi, Wahyu Bagja. (2012). Penyelewangan Dana Dalam Dunia Pendidikan. Fascho 1 (1), 1-9 